\title{
Et vanskelig samarbeid
}

Av GeIR Winje, Dosent ved Høgskolen i Sørøst-Norge. E-post: Geir.Winje@hbv.no

Jeg underviser i både barnehage- og grunnskolelærerutdanningene ved Høgskolen i Sørøst-Norge, stort sett innenfor feltet 'religiøst mangfold'. Etter praksisperiodene forteller alltid noen av studentene at de har vært med på aktiviteter som bryter med alt de har lært på høgskolen om å ikke diskriminere religioner og livssyn i forhold til hverandre. Dette gjelder særlig praksisperioder som ligger tett opp til jul eller påske.

Fremdeles meldes det om involverende jule- og påskevandringer, men også skolegudstjenester, ofte med preg av semesteravslutning. 'Fritak' innebærer ofte at noen få elever får lov til å kjede seg sammen $\mathrm{i}$ stedet for å delta i gudstjeneste i skoletiden. Det er fremdeles prester som forventer at elevene deltar aktivt, og lærere som tar en måneds pause fra læreplanen for å øve på sanger og forberede elevene på deltagelse $\mathrm{i}$ kirken. Etter min erfaring er det sjelden at personalet eller foreldrene diskuterer eller vedtar at Den norske kirke skal legge premissene for en så stor del av skolens virksomhet. Heller ikke elevene rådspørres, det har bare blitt sånn fordi det så lenge har vært sånn.

Det var derfor fint å lese Reidun Opsals artikkel «Påskevandring som samarbeidsprosjekt - kunnskapsformidling eller religionsutøvelse?» i Prismet nr. 1/2015. Her gis faktisk en del faglige og pedagogiske begrunnelser for å gjennomf $ø$ re påskevandring $i$ kirken som en del av undervisningen i KRLE (som i dette innlegget brukes synonymt med RLE). Artikkelen henter empiri fra observasjoner og intervjuer hun har gjort $\mathrm{i}$ forbindelse med sin masteroppgave med problemstilling: «Hvordan kan påskevandring $i$ kirkens regi fungere som et pedagogisk arbeidsredskap for RLE-undervisningen?». I det følgende trekker jeg fram og kommenterer kritisk ni av Opsals resonnementer og argumenter, slik jeg mener å lese dem mer eller mindre implisitt i artikkelen hennes (jeg har ikke lest masteroppgaven).

Det første resonnementet jeg vil kommentere, går slik: 1) Påskefortellingen er kulturarv. 2) «Elevene skal gjennom kjennskap til kulturarven utvikle kunnskap, dyktighet, og holdninger for å mestre livene sine.» 3) Fordi påskefortellingen er kulturarv, må alle elevene lære om den for å kunne utvikle «etisk, sosial og kulturell kompetanse».

Kommentar: Dette resonnementet begrunner hvorfor alle elevene bør lære om påskefortellingen, men det begrunner ikke påskevandring som metode. Snarere tvert imot: Dersom alle skal gjøres kjent med denne sentrale kristne fortellingen, må undervisningen gjennomføres slik at alle kan delta - det vil si på nøytral grunn og $\mathrm{i}$ regi av pedagoger, ikke prester eller kateketer.

Et annet resonnement jeg mener å finne i Opsals artikkel går slik: 1) FN's barnekonvensjon fastslår «barns rett til optimal utvikling, også på det åndelige og moralske område». 2) Skolen har derfor et ansvar 
for elevenes utvikling på det åndelige og moralske område.

Kommentar: Både barnekonvensjonen og andre menneskerettighetsdokumenter skal sikre religionsfriheten og foreldremandatet. De skal beskytte individ og familie mot overgrep fra staten. Det er med andre ord foreldrene, og ikke skolen, som har ansvaret for barnas utvikling «på det åndelige og moralske område» - i hvert fall fram til de som 16-åringer selv overtar dette ansvaret. Skolen forstås som statens forlengede arm; den må (som andre statlige institusjoner) holdes i sjakk. Den skal ikke blande seg inn i elevenes religiøse oppdragelse.

Et tredje resonnement: 1) «Skolens målsetting er at kulturarv og religionenes fortellinger og praksis skal være byggeklosser i elevens utvikling av identitet og livstolkning», 2) elevene må derfor få tilgang til så mange byggeklosser (dvs elementer fra kulturarven, religiøse fortellinger og religiøs praksis) som mulig. 3) Skolen skal se til at dette fører til identitetsutvikling og 4) livstolkning.

Kommentar: Utsagnet i punkt 1 ovenfor virker som Opsals egen tolkning, og ikke noe sitat. Det er uklart hva som menes med at «religionenes (...) praksis skal være byggeklosser». Elevene skal selvsagt lære om religionenes praksis, men de skal ikke selv praktisere religion i skolens regi. Begrepet «identitet» er også problematisk. Skolens identitetsideal er skriftliggjort i Generell del av læreplanen, det er individualistisk og integrert, med front mot både førmoderne «gruppeidentitet» og senmoderne «fragmentert identitet». I resonnementet ovenfor tillegges skolen et ansvar for elevenes identitetsutvikling som den ikke har, i hvert fall ikke når identitet knyttes til «liv- stolkning» og «religionenes fortellinger og praksis».

Det fjerde resonnementet jeg vil trekke fram, går - slik jeg leser det - som følger: 1) KRLE-faget har en objektiv «forsiktighetsprofil», 2) noe som blant annet medfører «utelukkelse av involverende, deltagende og erfaringsrike aktiviteter». 3) Dette fører også til en «mer kritisk tilnærming til religioner som stimulans til personlig utvikling».

Kommentar: Skal dommene i FNs menneskerettighetskomité (2004) og Den europeiske menneskerettighetsdomstolen i Strasbourg (2007) tas til følge, bør vi legge diskusjonen om involvering i KRLE død, og i stedet konsentrere oss om hvordan vi kan gjennomføre engasjerende undervisning uten å påvirke elever i retning av en spesiell tro. For $\emptyset$ vrig behøver ikke en lærer være kritisk til religion selv om hun er kritisk til involverende og deltakende undervisningsformer.

For det femte skriver Opsal: 1) «Ved hjelp av sanser og erfaringer gjennom kroppslig aktivitet får barn en $\emptyset \mathrm{kt}$ motivasjon og en dypere forståelse og innsikt i det som skal læres.» 2) Når elevene legger blomster på alteret, vifter med «palmegrener», roper «Hosianna», får smake på «nattverdsbrød» og synger kristne sanger, lærer de ved å bruke sanser og gjøre erfaringer gjennom kroppslig aktivitet. 3) Slik oppfyller skolen sitt ansvar for å gi elevene «opplevelse, erfaring og involvering» og få «en adekvat forståelse av hva religion er» gjennom erfaringslæring.

Kommentar: Skal en bruke slike arbeidsmåter $\mathrm{i}$ forbindelse med alle religionene i KRLE, blir det ganske sikkert protester - først og fremst fordi de er så involverende. Dette er så langt jeg kan se, 
en form for dramatisering der elevene inntar roller som Jesustilhengere. Læreplanen poengterer: «I undervisningen skal det ikke være forkynnelse eller religionsut$\emptyset$ velse. Likeverdige pedagogiske prinsipper skal legges til grunn.» Er det greit å dramatisere religionsutøvelse når det ikke er greit å utøve religion «på ordentlig»? Det kan videre virke som om det kun er de som praktiserer en religion, som tillegges «en adekvat forståelse» av den. Skolen skal formidle forskningsbasert kunnskap om religioner, uten at elevene skal måtte erfare noe som helst. Den norske kirke kan i likhet med andre trossamfunn tilby erfaringsbasert forståelse (utenom skoletid). Og dersom en «adekvat forståelse» av en religion avhenger av elevenes «opplevelse, erfaring og involvering», må skolen overlate undervisningen til trossamfunnene. Da går vi glipp av det unike med KRLE, nemlig at elever med ulik bakgrunn snakker sammen om religion.

Opsals sjette argument: 1) «Faren for at religion blir oppfattet som noe teoretisk, gammelt og avleggs og for spesielt interesserte, er til stede». 2) Påskevandring og lignende metoder kan motvirke dette.

Kommentar: En «adekvat forståelse» synes å innebære at religion forstås som noe annet enn «teoretisk, gammelt, avleggs og for spesielt interesserte». Men er det skolens oppgave å motarbeide en slik opplevelse? Slik jeg forstår religionsfrihet, skal alle få tenke og tro hva de vil om religion - også at den er avleggs. Når KRLE gir elevene saklig kunnskap om religion, blir synsingen forhåpentligvis mer kvalifisert, men elevene behøver ikke bli spesielt interesserte i religion av den grunn.

Det sjuende resonnementet er - hvis jeg forstår det riktig - slik: 1) John Hull har utviklet en modell som blant annet skjelner mellom å lære om religioner og livssyn og å lære av religioner og livssyn. 2) Elevene bør derfor lære både om og av religioner og livssyn. 3) Påskevandring er et eksempel på å lære av.

Kommentar: Når Hull og andre hevder at elevene lærer av religion, er det fordi elevene lærer noe av alt de møter. Det må læreren være klar over, og hun må ta noen valg når det gjelder å gi retning til samtalen i kjølvannet av en religiøs fortelling. Når Hull og andre skjelner mellom å lære av og å lære om, skjelner de samtidig mellom en allmennmenneskelig og en mer religionsspesifikk tilnærming. Begge er verdifulle og nødvendige, men de bør ikke sammenblandes på en ukritisk måte. For eksempel kan alle elever - uansett religiøs bakgrunn - lære noe av påskefortellingen, så vel som av hverandre, når samtalen dreier seg om allmennmenneskelige forhold som døden. Når samtalen tar for seg et mer religionsspesifikt tema, som for eksempel at Jesus på korset i henhold til kristen tro er Guds sønn og frelser, lærer elevene om dette religionsspesifikke kristne poenget - men ikke av det.

Det åttende argumentet: 1) Ninian Smart har utviklet en modell som egner seg når en skal beskrive og analysere religion. Her opererer han med sju dimensjoner - blant annet en erfarings- eller følelsesdimensjon. 2) Fordi religionene har en erfaringseller følelsesdimensjon, bør elevene erfare og føle når de lærer om en religion.

Kommentar: Alle Smarts dimensjoner, både den dogmatiske, den narrative, den rituelle og de andre kan fungere som innfallsvinkler når elever skal lære noe om religion. Skal en elev unders $\emptyset$ ke den psykologiske dimensjonen (følelsesdimensjonen) 
ved en religion han ikke tilhører selv, kan han for eksempel intervjue en som tilhører den aktuelle religionen.

Det siste resonnementet jeg vil hente fram er at 1) fordi fritaksretten var i bruk under de observerte påskevandringene, 2) hadde de som deltok, « grønt lys» hjemmefra.

Kommentar: Påskevandring og lignende aktiviteter bør etter mitt syn avvikles, da de knytter faget altfor tett til Den norske kirke. Men så lenge regjeringen aksepterer slike arbeidsformer, vil de neppe forsvinne. I så fall bør foreldrene få hyppig og grundig informasjon, skole-kirke-samarbeidet bør drøftes i foreldreutvalg og foreldremøter, og det bør være påmelding, ikke avmelding, til slike aktiviteter. Bruken av fritaksretten er i mange tilfeller en konsekvens av dårlig planlegging, da fritak splitter elevene.
Det er ekstra uheldig når det gjelder religion, der fordommene er store og kunnskapsbehovet likeså. Fritak kan ha noe for seg når det er viktig for et trossamfunn å oppøve barns evne til ikke-deltagelse, slik som Jehovas vitner gjør. I slike tilfeller bør læreren kunne forklare de andre elevene hvorfor noen ikke deltar i visse aktiviteter, på en måte som signaliserer respekt og ivaretar vitnenes selvrespekt.

Alt i alt mener jeg altså at Opsal argumenterer for en metodikk som tar for lite hensyn til det strenge regelverket for KRLE. I artikkelen begrunner og forsvarer hun en praksis som kombinerer et altfor eksistensielt mål med en altfor involverende metodikk, noe som vanskeliggjør reell religionsfrihet i KRLE. 